\title{
IMPLEMENTASI SUPERVISI AKADEMIK TERHADAP KINERJA GURU DI SMA NEGERI 1 KEC. PADANG TUALANG KAB. LANGKAT
}

\author{
${ }^{1}$ Kholidaziah, ${ }^{2}$ Hamidah D, ${ }^{3}$ Irwan \\ Mahasiswa STKIP Budidaya Binjai \\ $\mathbf{1}_{\text {ziahsimanjuntak15@gmail.com }}$ \\ Dosen STKIP Budidaya Binjai \\ 2darmahamidah@gmail.com \\ 3irwanmedan@gmail.com
}

\begin{abstract}
ABSTRAK
Tujuan Penelitian ini untuk mengetahui bagaimana Implementasi Supervisi Akademik yang dilakukan Kepala Sekolah dalam meningkatkan kinerja guru. Penelitian ini di laksanakan di SMA Negeri 1 Padang Tualang Kab. Langkat. Metode yang digunakan dalam penyusunan Skripsi ini adalah Deskriptif dengan pendekatan Kualitatif. Alat pengumpul data mengunakan observasi, wawancara, dan dokumentasi. Adapun narasumber penelitian ialah kepala sekolah, wakil kepala sekolah, dan guru mata pelajaran di SMA Negeri 1 Kec. Padang tualang Kab. Langkat. Hasil penelitian menyatakan proses supervisi akademik yang dilakukan kepala sekolah melalui beberapa tahapan (1) Perencanaan supervisi akademik (2) Teknik supervisi akdemik (3) Evaluasi supervisi akdemik dalam meningkatkan kinerja guru. Kepala sekolah telah memiliki tanggungjawab yang besar dalam menbantu segala permasalahan dan kebutuhan guru untuk mensukseskan pembelajaran yang bermutu di sekolah agar tercapainya tujuan pembelajaran yang efektif dan efesien. Berdasarkan penjelasan di atas disimpulkan Implementasi supervisi akademik kepala sekolah haruslah memiliki program kerja, melakukan pengawasan, mengukur dan menilai dari hasil kinerja yang telah dilakukan, maka dapat meningkatkan kualitas kerja para guru menjadi lebih baik.
\end{abstract}

Kata kunci: implementasi, supervisi akademik, kinerja guru

\section{ABSTRACT \\ IMPLEMENTATION OF ACADEMIC SUPERVISION ON PERFORMANCE TEACHER AT SMA NEGERI 1 KEC. PADANG TUALANG}

The purpose of this research is to determine how the implementation of academic supervision by the principal in improving teacher performance. This research was conducted at SMA Negeri 1 Padang Tualang Kab. Langkat. The method used in the preparation of this thesis is descriptive with a qualitative approach. Data collection use observation, interviews, and documentation. The research sources were the principal, vice principal, and subject teachers at SMA Negeri 1 Kec. Padang Tualang Kab. Langkat. The results showed that the academic supervision process carried out by the principal went through several stages (1) Planning for academic supervision (2) Academic supervision techniques (3) Evaluating academic supervision in improving teacher performance. The school principal has a big responsibility in helping all the problems and needs of teachers to make quality learning successful in schools in order to achieve effective and efficient learning goals. Based on the explanation above, it is concluded that the implementation of the principal's academic supervision must have a work program, supervise, measure and assess the results of the performance that has been done, it can improve the quality of the work of teachers for the better.

Keywords: implementation, academic supervision, teacher performance 


\section{PENDAhuluan}

Kepala sekolah sangat berperan penting di sekolah, untuk itu kepala sekolah atau pemimpin sekolah harus mampu mendorong percaya diri guru dan juga siswa dalam menjalankan tugasnya masing-masing demi kemajuan sekolah dalam mencapai tujuan. Karena maju mundurnya kondisi sekolah dan tinggi rendahnya kualitas lulusannya itu semua tidak lepas dari peran kepala sekolah. Salah satu tugas kepala sekolah melaksanakan supevisi akademik, dalam suatu lembaga pendidikan kepala sekolah merupakan pemimpin pendidikan yang mempunyai peran yang sangat besar dalam mengembangkan mutu pendidikan di sekolah (Wahyosudmidjo,2011: 203).

Supervisi akademik adalah kegiatan supervisi yang dilakukan untuk perbaikan proses belajar mengajar. (Sudarwan, 2017:153). Sedangkan menurut Sudiyono (2011:84), supervisi akademik adalah serangkaian kegiatan membantu guru mengembangkan kemampuannya mengelola proses pembelajaran untuk mencapai tujuan pembelajaran. Supervisi akademik bisa dikatakan juga sebagai supervisi kontekstual yaitu upaya membina guru-guru dalam mengembangkan proses pembelajaran pada daerah tertentu yang mencakup unsur-unsur, materi pembelajaran, proses pembelajaran, kecakapan hidup yang dibutuhkan, tingkat kompetensi setiap guru, dan kondisi para siswa (Pidarta, 2009: 2).

Supervisi akademik merupakan upaya membantu guru-guru mengembangkan kemampuannya mencapai tujuan pembelajaran. Sebab kemampuan organisasi sekolah dalam menyelengarakan pendidikan atau pembelajaran yang bermutu tidak semata ditentukan oleh profesionalitas guru dalam mengelola pembelajaran, namun juga ditentukan oleh pengelolaan organisasi sekolah yang efektif. Oleh karena itu, seorang kepala sekolah harus mengusai konsep dasar supervisi, teknik-teknik supervisi sampai pada penilaian dan perbaikan bagi guru, karena hakikat supervisi adalah membantu guru untuk meningkatkan kompetensinya, supervisi yang dilakukan kepala sekolah adalah merupakan supervisi secara langsung, karena kepala sekolah mempunyai peluang waktu yang sangat besar untuk bisa bertatap muka dengan dewan guru, sehingga peran kepala sekolah terlaksana dengan baik.

Kinerja guru merupakan komponen utama dalam proses pendidikan atau pembelajaran di sekolah. Kinerja adalah tingkat keberhasilan seseorang atau kelompok orang dalam melaksanakan tugas dan tanggung jawabnya serta kemampuan untuk mencapai tujuan dan standar yang telah ditetapkan. Guru menjadi salah satu ujung tombak pembangunan mutu pendidikan atau pembelajaran. Dengan dukungan unsur organisasi sekolah lainnya, guru dapat menjalankan tugas melaksanakan proses pembelajaran dengan efektif bila hal itu bersinergi dengan kompetensi yang dimiliki oleh guru itu sendiri.

Untuk melihat dan menilai serta membantu kinerja guru agar semua kegiatan yang telah terprogram dapat berjalan secara efektif serta sesuai dengan apa yang telah direncanakan diperlukan pengawasan atau supervisi oleh kepala sekolah. Bahwa pengawasan atau supervisi pendidikan tidak lain dari usaha memberikan layanan kepada pendidikan, terutama kepada guru-guru, baik kepada guru maupun kepada kelompok dalam usaha memperbaiki kualitas proses dan hasil pembelajaran.

Hasil observasi awal yang peneliti lakukan menunjukan bahwa kinerja guru masih dihadapkan pada permasalahan pembelajaran dikelas bersumber dari pribadi guru itu sendiri, diantaranya (1) guru tidak tepat waktu hadir disekolah, (2) guru tidak masuk kelas pada jam pelejaran, (3) suasana pembelajaran dikelas tidak kondusif seperti terdapat murid-murid yang ribut dan keluar kelas tanpa izin guru, (4) guru meningalkan kelas sebelum jam pelajaran selesai. Oleh sebab itu diperlukan supervisi akademik oleh kepala sekolah yaitu dengan adanya perhatian terhadap pegelolaan proses belajar mengajar terutama untuk melihat langsung proses pembelajaran dikelas yang dilakukan oleh guru, dan pada akhirnya untuk meningatkan kualitas belajar dikelas dan serta meningkatkan prestasi peserta didik. 


\section{METODE PENELITIAN}

Penelitian ini dilakukan untuk mengkaji Implementasi Supervisi Akademik Terhadap Kinerja Guru di SMA Negeri 1 Padang Tualang Kab. Langkat. Dengan tujuan seperti ini pendekatan yang lebih cocok digunakan adalah penelitian kualitatif. Pendekatan kualitatif yang akan saya gunakan bersifat deskriptif, dimana dalam penelitian ini lebih menekankan pada makna, gambaran, keadaan dan proses daripada hasil suatu aktivitas.

Penelitian ini dilakukan di SMA Negeri

1 Padang Tualang Kab. Langkat. Subjek penelitian ini yaitu kepala sekolah dan guru di SMA Negeri 1 Padang Tualang.

Sumber data yang digunakan untuk memperoleh data dalam penelitian ini dapat penulis bagi kepada dua macam diantaranya, yaitu:

a. Sumber data primer, yaitu sumber data pokok yang diterima langsung dari kepala sekolah, wakil kepala sekolah dan guru.

b. Sumber data sekunder, diperoleh dari dokumen-dokumen, data-data, serta bukubuku referensi yang membahas permasalahan penelitian tersebut yang diperoleh dari Tata Usaha (TU).

Untuk memperoleh data dalam penelitian ini, penulis menggunakan observasi, wawancara dan dokumentasi

Setelah melakukan observasi dan wawancara peneliti melakukan dokumentasi yaitu dokumen yang ada karena dicetak, ditulis dan digambar sesuai dengan yang peneliti lakukan untuk memperoleh data dan informasi yang diharapkan dalam penelitian ini juga dilakukan melalui pengkajian berbagai dokumen yang dibutuhkan untuk memperoleh data.

\section{HASIL PENELITIAN DAN PEMBAHASAN}

\section{Perencanan Program Supervisi Akademik Di SMA Negeri 1 Padang Tualang.}

Dalam hal ini perencanaan ialah suatu program yang dibuat kepala sekolah untuk mencapai tujuan pendidikan, perencanaan kepala sekolah dalam meningkatkan kinerja guru di SMA Negeri 1 padang tualang.
Hasil wawancara kepada kepala sekolah mengenai pelaksaan perencanaan supervisi akademik oleh kepala sekolah SMA Negeri 1 padang tualang sebagai berikut:

"Perencanaan yang saya buat disini diawal tahun ajaran baru biasanya saya mengadakan rapat diawal ajaran baru guna untuk mempersiapkan perangkat pembelajaran disetiap bidang studi, dirapatkan dengan guruguru seperti RPP, silabus Prosem, kemudain prota yang harus dipersiapkan oleh guruguru',

Wawancara kepada kepala sekolah diatas menunjukan bahwasanya kepala sekolah melakukan perncanaan dalam kegiatan supervisi akadmeik disekolah ini, hal ini didukung dengan hasil wawancara dengan wakil kepala sekolah SMA Negeri 1 Padang Tualang, megenai kegiatan kepala sekolah yang merencakan supervisi sebagai berikut

"Biasanya kita buat jadwal, memang supervisi akademik ini tidak berjadwal dan kepala sekolah juga setiap saat dan setiap hari juga masuk, namun untuk mempersiapkan itu terlebih dahulu kita buat jadwal'".

Dari hasil wawancara dengan wakil kepala sekolah dapat disimpulkan bahwasanya memang melaksankan perencanan supervisi akademik disekolah ini, membuat perencanaan lalu mendiskusikannya.

Perencanaan Supervisi Akademik di SMA Negeri 1 Padang Tualang perlu dilakukan apakah guru sudah mempersipakan rencana pelaksanan pembelajaran (RPP), materi pembelajaran, metode yang dilakukan guru dalam proses pembelajaran.

Wawancara dengan guru mata pelajaran Fisika beliau mengatakan:

"iya dilaksankan, karena memang setiap tahuan itu kan guru sudah di suruh membuat RPP, kemudian di supervisi apakah pelaksanaan pembelajaran sesuai dengan RPP, kemudian pada pertengahan dilihat hasilnya, dam pada akhir semester juga dilihat dari hasil siswanya",

Berdasarkan hasil wawancara kepada kepala sekolah, wakil kepala sekolah dan guru, bahwasanya kepala sekolah melaksanakan perencanaan supervisi akademik sudah terjadwal dengan bidang studi masing-masing 
sehingga guru mendapat pengawasan dari kepala sekolah.

Tahapan-tahapan

pelaksanaan

perencanaan supervisi akademik di SMA Negeri 1 Padang Tualang, sebagaiman dijelaskan oleh kepala sekolah sebagai berikut:

"saya selaku kepala sekolah disini dalam pelaksaan supervisi akademik ini yang pertama saya periksa perangkat pembelajaran guru seperti (RPP), silabus. Saya saya mengadakan rapat guru untuk selanjutnya saya mengadakan kunjungan kelas, untuk melihat guru dalam proses pembelajaran',

Dari wawancara kepada kepala sekolah dapat disimpulkan bahwa pelaksanaan supervisi akademik yang dilakukan secara bertahap, yang pertama itu memeriksa kelengkapan perangkat pembelajaran, kedua mengadakan musyawarah atau rapat guru, dan ketiga melakukan kunjungan kelas. Pelaksanaan supervisi akademik yang dilakukan oleh kepala sekolah dilaksanakan setiap semester sesuai kalender pendidikan.

Hasil wawancara dengan wakil kepala sekolah mengenai ketercapaian program yang telah dibuat beluau berkata:

" alhamdulillah pelaksanaan berjalan baik, guru-guru mempersiapkan perangkat pembelakaran seperti RPP,media pembelajaran serta metode yang digunakan.

Dari wawancara dengan wakil kepala sekolah tersebut dapat disimpulkan bahwa pelaksanaan supervisi akademik di SMA Negeri 1 Padang Tualang ini sebagai wakil kepala sekolah juga sudah mengetahui sebagai tugasnya membantu kepala sekolah ikut serta melakukan pengawasan kepada guru-guru dalam proses pemeblajaran.

Sejalan dengan hasil wawancara guru mata pelajaran Fisika beliau mengatakan:

"Pelaksanaan yang dilakukan oleh kepala sekolah bagus, saya sangat mendukung kegiatan yang dilakukan kepala sekolah karena tujuannya untuk mengevaluasi sejauh mana kita mengajar dikelas agar dapat membantu para guru khususnya dalam menghadapi permasalahan yang kami temukan di dalam mempersiapkan yang berhubungan dengan proses pembelajaran".

Dari hasil wawancara dengan kepala sekolah, wakil kepala sekolah dan juga guru- guru, bahwasanya wakil kepala sekolah sangat medukung perencanaan program supervisi akademik yang dilakukan kepala sekolah begitu juga para guru-guru sangat mendukung kegiatan yang dilakukan kepala ekolah karen bertujuan mengevaluasi sejauh mana proses mengajar dikelas para guru guru.

\section{Teknik Supervisi Akademik di SMA Negeri 1 Padang Tualang}

Teknik supervisi yang dilakukan di SMA Negeri 1 padang tualang dengan berbagai teknik dan metode dengan harapan agar tujuan dari supervisi dapat dicapai dengan efektif dan efisien. Teknik supervisi yang digunakan disesuaikan dengan kebutuhan, situasi dan kondisi yang ada. Teknik supervisi yang digunakan yaitu secara individu dan maupun kelompok. Teknik yang dilakukan kepala sekolah antara lain:

"Teknik supervisi yang saya lakukan selaku kepala sekolah di SMA Negeri 1 padang tualang ini yaitu tergantung kondisi yang ada.Teknik supervisi secara individu dapat digunakan untuk mendapatkan hasil yang maksimal yaitu dengan kunjungan kelas, yang mana pertama saya lakukan dengan mendatangi ke kelas-kelas. Apabila terdapat kondisi yang tidak memungkinkan serta keterbatasan waktu maka saya menggunakan teknik supervis kelompok yaitu mengelompokkan guru yang memiliki permasalahan sehingga lebih efisien".

Dari hasil wawancara dengan wakil kepala sekolah SMA Negeri 1 Padang Tualang, menjelaskan tentang teknik supervisi yang dilakukan oleh kepala sekolah sebagai berikut:

"Kunjungan kelas yaitu langsung ke kelas ada juga di depan pintu kelas, mendengar dan melihat apa yang dilakukan oleh guru di dalam apakah benar-benar membawa Rencana Perangkat Pembelajaran (RPP) atau hanya sekedar mengajar datang lalu catat. Kemudian diadakan rapat dan dibicarakan bagaimana seharusnya guru mengajar dengan baik dan benar".

Dari hasil wawncara di atas dapat disimpulkan bahwa teknik supervisi yang dilakukan oleh kepala sekolah secara individual atau secara kelompok dengan melihat situasi dan kondisinya. Teknik supervisi secara individual dilakukan dengan cara kunjungan 
kelas atau observasi kelas, sedangkan teknik supervisi secara kelompok dengan cara mengelompokkan guru yang mempunyai permasalahan untuk dilakukan tindak lanjut.

Hasil wawancara dengan guru fisika beliau menyatakan sebagai berikut:

"Biasanya kepala sekolah melakukannya dengan kunjungan kelas, kami mengajar di depan kemudian kepala sekolah datang dan melihat bagaimana proses belajar mengajar guru di kelas apakah sesuai dengan RPP yang kita buat".

Dari pernyataan guru fisika dapat disimpulkan bahwa teknik supervisi akademik yang dilakukan kelapa sekolah dan wakil kepalas sekolah dengan teknik individu dan kelompok.

Dalam pelaksanaan suatu program pasti tidak terlepas dari hambatan dan kesulitan, berikut ini beberapa faktor hambatan yang terjadi dalam suatu program yang jelaskan kepala sekolah SMA Negeri 1 Padang Tualang sebagai berikut:

"Yang menjadi faktor penghambat dalam pelaksanaan supervisi akademik yaitu masih terdapat guru yang tidak susai mengajar dengan apa yang tertulis di RPP".

Hasil wawancara dengan wakil kepala sekolah SMA Negeri 1 padang tualang sebagai berikut

"iya ada beberapa kendala yang dihadapi guru-guru yaitu guru yang tidak membuat Rencana Perangkat Pembelajaran (RPP) karena biaya untuk praktek, dan apalagi diawal-awal semester perangkat pembelajaran itu belum siap dibuat oleh guru maka disitu kendalanya".

Sejalan dengan hasil wawancara kepada guru mata pelajaran fisika mengungkapkan:

"Kendalanya karena waktu, kadang kepala sekolah tersebut tidak punya waktu dan biasanya terjadwal. Kepala sekolah membuat jadwal nanti diberitahunya dalam diskusi atau rapat bahwa ibu hari ini bulan ini. Jadi gak selalu kita aja, semua bergantian".

Dari pemaparan guru mata pelajaran fisika mengenai hambatan yang dialami dalam pelaksanaan supervisi akademik kepala sekolah, Pelaksanaan Supervisi Akademik di SMA Negeri 1 Padang Tualang yang dilakukan kepala sekolah menurut mereka tidak keberatan karena itu sangat bagus untuk dilaksanakan kepada guru-guru sehingga bisa memperbaiki dimana kekurangan dan kelebihan dan manakah yang salah apakah sesuai dengan RPP yang dibuat. Hanya saja kendala atau hambatan yang terjadi disebabkan karena biaya bahan praktek dan waktu yang belum memadai sehingga menghambat pelaksanaan

Hambatan atau kesulitan sering kali terjadi dalam melaksanakan suatu program yang ingin kita capai. Hambatan atau kesulitan tidak menjadi sebuah masalah yang besar apabila kita dapat menghadapi suatu permasalahan dengan baik.

\section{Evaluasi Supervisi Akademik di SMA Negeri 1 Padang Tualang}

Berdasarkan hasil wawancara dengan kepala sekolah mengenai evaluasi dari program supervisi akademik mengatakan:

"Alhamdulillah, ada perubahanperubahan khususnya peningkatan dari guruguru yang tadi awalnya belum paham menjadi paham. terutama persiapan perangkat pembelajarannya itu tadi apakah lengkap atau tidak sudah baik atau belum baik".

Berdasarkan pendapat kepala sekolah dapat disimpulkan bahwa evaluasi yang dilakukan kepala sekolah dapat meningkatkan hasil kerja guru

Berdasarkan wawancara dengan wakil kepala sekolah sebagai berikut:

"kita lihat dari hasil belajar siswa apakah sudah mencapai KKM, Alhamdulillah, ketercapaian supervisi yang diterapkan kepala sekolah sudah diterapkan oleh guru dan dilakukan oleh guru semaksimal mungkin",

Dari hasil wawancara di atas, dapat disimpulkan bahwa evaluasi yang dilakukan kepala sekolah atas kinerja guru dalam menyampaikan pembelajaran, karena itu keberhasilan siswa dalam suatu proses pembelajaran sangat ditentukan oleh guru.

Sejalan dengaan wawancara dengan guru fisika sebagai berikut:

"Yang jelas kita bisa lihat dari hasil pencapaian anak-anak tadi setelah disupervisi apakah guru itu sudah melaksanakan tugasnya itu sebagai guru atau tidak, materinya sudah sampai atau belum, kan bisa dilihat dari situ dari hasil anak-anak tersebut". 
Dari hasil wawancara di atas bahwa evaluasi yang dilakukan kepala dapat memotivasi para guru untuk menjadi lebih baik lagi pada saat membuat perangkat pembelajaran dan proses pembelajaran dilakukan.

Berdasarkan pada paparan di atas, hasil yang dapat dikemukakan dalam kaitan dengan Implementasi Supervisi Akademik kepala sekolah terhadap kinerja guru di SMA Negeri 1 Padang Tualang.

Implementasi dari pelaksanaan supervisi kepala kepala sekolah yang melibatkan kepala sekolah dan wakil kepala sekolah sebagai supervisor, guru yang disupervis diharapkan dapat meningkatkan kinerja guru yang disupervisi serta dapat mengembangkan kegiatan pembelajaran. Penelitian ini menunjukkan bahwa dapat dilihat perencanaan supervisi akademik kepala sekolah dalam meningkatkan kinerja guru di SMA Negeri 1 padang tualang sudah tersusun dengan benar sesuai dengan ketentuan yang ada. Perencanaan dalam supervisi akademik yang dilakukan yaitu pertama kepala sekolah menetapkan tujuan, kedua melakukan diskusi bersama wakil kepala sekolah dan para guru lainnya dengan musyawarah/ rapat, dan ketiga melaksanakan jadwal supervisi akademik.

Sebelum pelaksanaan pembelajaran dilaksankan perencanaan yang harus dipersiapkan yaitu diantaranya kurikulum, silabus, program tahunan, program semester, rencana program pembelajaran (RPP), serta materi, metode dan media pembelajaran. Perancanaan yang dilakukan oleh kepala sekolah SMA Negeri 1 Padang Tualang terjadwal sehingga semua guru-guru yang mengajar di sekolah tersebut mendapat pengawasan dari kepala sekolah.

Pelaksanaan yang dilakukan kepala Sekolah SMA Negeri 1 Padang Tualang kab. Langkat sudah benar dimana pertama kali yang dilakukan kepala sekolah memeriksa kelengkapan perangkat mengajar guru, kedua mengadakan rapat kepada guru-guru, dan ketiga kepala sekolah melakukan kunjungan kelas sesuai jadwal yang telah dibuat.

Dengan adanya kegiatan supervisi ini membantu guru untuk mengetahui kekurangan dan kelebihan dirinya dalam menyiapkan suatu program pembelajaran, karena supervisi ini gunanya adalah bantuan yang diberikan kepala sekolah dalam meningkatkan kinerja guru.

Penelitian ini menunjukkan kepala sekolah SMA Negeri 1 Padang Tualang kab. Langkat, dalam melaksanakan kegiatan supervisi menggunakan teknik supervisi yaitu secara individual atau secara kelompok dengan melihat situasi dan kondisi yang ada. Teknik secara individual dilakukan dengan cara kunjungan kelas atau observasi kelas kepala sekolah melihat langsung sendiri aktivitas guru dalam proses pembelajaran, sedangkan teknik secara kelompok yaitu dengan cara mengumpulkan guru atau rapat. Teknik individual dan kelompok ini, memberikan bantuan kepada tenaga kependidikan, khususnya guru sehingga proses pembelajaran berlangsung secara efektif dan efisien.

Penelitian ini relevan dengan penelitian yang dilakukan Mintadji dengan judul "Implemetasi Supervisi Akademik Kepala Sekolah SMP Negeri di Tarakan". Metode penelitian yang dilakukannya mengunakan pendekatan kualitatif, yaitu data yang digunakan berasal dari obyek, tempat dan prosedur yang digunakan prosedur tak baku karena data berasal dari kondisi yang nyata di SMP Negeri Tarakan tentang implementasi supervisi akademik. Analisis data penelitian ini adalah analisis deskriptif melalui kegiatan observasi, wawancara dan studi dokumentasi.

Penelitian serupa juga dilakukan oleh Ainon Mardhiah, dkk dengan judul "Peningkatakan Profesional Guru Melalui Supervisi Akademik di SMP Negeri 3 Peusangan Kabupaten Bireuen". Metode yang penelitian yang digunakan jeniis penelitian kualitatif. Pendekatan ini mengunakan strategi penelitian seperti naratif, fenomenologis, etnografis, studi groundel theory, atau studi kasus. Penelitian mengumpulkan data penting secara terbuka terutama dimaksudkan untuk mengembagkan tema-tema dari data. Hasil penelitian menunjukan bahwa pelaksankaan supervisi oleh kepala sekolah SMP Negeri 3 peusangan kabupaten bireuen belum begitu maksimal.

\section{KESIMPULAN DAN SARAN}

\section{A. Kesimpulan}


Berdasarkan pembahasan yang telah dilakukan, maka dapat diambil beberapa kesimpuan perencanaan supervisi akademik kepala sekolah dalam meningkatkan kinerja guru di SMA Negeri 1 Padang Tualang Kab. Langkat bahwa perencanaan program ssupervisi akademik kepala sekolah telah disusun dengan cukup baik namun ada aspek yang perlu ditingkatkan yaitu pentingnya peningkatan pengetahuan terhadap perencanaan supervisi yang merujuk kepada permasalahan yang dihadapi guru di S Negeri 1 Padang Tualang Kab. Langkat, adapun Teknik supervisi akademik yang dilakukan kepala sekolah dalam meningkatkan kinerja guru di SMA Negeri 1 Padang Tualang Kab. Langkat, adalah melakukan teknik supervisi yang bersifat individu dengan mengadakan kunjungan kelas atau observasi kelas dan teknik supervisi secara kelompok, terlebih dahulu memeriksa perangkat pembelajaran yang dibuat oleh guru yaitu guru-guru sudah melakukan persiapan sebelum pembelajaran dilakukan seperti membuat silabus, Rencana Program Pengajaran (RPP) sebagai pedoman dalam mengajar. Evaluasi terhadap kegiatan supervisi akademik yang dilakukan oleh kepala sekolah dalam meningkatkan kinerja guru yang dilakukan kepada guru untuk mengetahui sejauh mana peningkatan kinerja guru telah berjalan apakah sudah lebih baik atau belum. sehingga kedepannya dapat meningkatkan potensi yang kita miliki agar tujuan dari pembelajaran tersebut tersampaikan kepada peserta didik dengan efektif dan efisien.

\section{B. Saran}

Berdasarkan kesimpulan diatas yang ditemukan, peneliti menyarankan bagi kepala sekolah perlunya meningkatkanpengetahuan tentang supervisi akademik agar dapat memimpin sekolah dengan baik, memberikan pengetahuan sera dorongan kepada guru-guru dalam melaksankan tugasnya, dan guru hendaknya saling kerja sama antara kepala sekolah dan guru sehingga tercapai tujuan dengan baik.

\section{DAFTAR PUSTAKA}

Alamsyah, Yosep Aspat. 2016. Expert Teacher (Membedah syarat-syarat untuk menjadi Guru Ahli atau Expert Teacher). Vol.3 No.1 diakses 20 April 2020. http:-ejournal.radenintan.ac.id-index.phpterampil-article-view-1328

Dede, Mudzakir. 2016. “Implementasi Supervisi Manajerial dan Akademik Pengawas Dalam Meningkatkan Kinerja Guru Pendidikan Agama Islam Madrasah Ibtidaiyah. Vol. 10 No 2 diakses 20 April 2020

http:--jurnaluinbanten.ac.id-index.php$\underline{\text { studiadidkatika-article-view-18 }}$

Harahap, Winata Angga dan D., 2019. Hamidah, 2016, Optimalisasi Peran Guru Dalam Proses Pembelajaran, Jurnal Serunai. Vol. 8 (1).

Mintadji, 2015. "Implemetasi Supervisi Akademik Kepala Sekolah SMP Negeri di Tarakan. Jurnal Kebijakan dan pengembangan Pendidikan, Vol. 3 (1). HIm, 82-87

Mardhiah, Ainon, dkk, "Peningkatkan Profesional Guru Melalui Supervisi Akademik di SMP Negeri 3 Peusangan Kabupaten Bireuen". Jurnal Administrasi Pendidikan Pascasarjana Unsyiah, Vol. 2 (2). Hlm. 1-11

Prasojo dan Sudiyono. 2011. Supervisi Pendidikan. Yogyakarta: Gaya Media

Pidarta Made. 2009. Supervisi kontekstual. Jakarta : Rineka Cipta

Wahjosumidjo. 2011. Kepemimpinan Kepala Sekolah. Jakarta: PT. RajaGrafindo Persada.

Wahyudi, M. Dian. 2014. Hubungan Persepsi Guru Tentang Perilaku Kepemimpinan Transformasional Kepala Sekolah dan 
Iklim Komunikasi Dengan Kinerja Guru SD Negeri Di Kecamatan Binjai Timur Kota Binjai, Diakses 20 April 2020.

http://digilib.unimed.ac.id/4239/9/9.\%20

8116131014\%20Bab\%20I.pdf 